\title{
Application of Indonesian's National Standard for Grouping of Bali Cattle with Cluster and Biplot Analysis
}

\author{
I Putu Sampurna1, Tjokorda Sari Nindhia ${ }^{2}$, Ni Nyoman Werdi Susari ${ }^{3}$, I Ketut Suatha ${ }^{4}$ \\ ${ }^{1}$ Biostastic Laboratory, Faculty of Veterinary Medicine, \\ Udayana University, Bali, Indonesia \\ Email: putu_sampurna@unud.ac.id \\ ${ }^{2}$ BiostasticLaboratory, Faculty of Veterinary Medicine, \\ Udayana University, Bali, Indonesia \\ Email: sari_nindhia@unud.ac.id \\ ${ }^{3}$ Veterinary Anatomy Laboratory, Faculty of Veterinary Medicine, \\ Udayana University, Bali, Indonesia \\ Email: nwsusari@unud.ac.id \\ ${ }^{4}$ Veterinary Anatomy Laboratory, Faculty of Veterinary Medicine, \\ Udayana University, Bali, Indonesia \\ Email: iksuatha@unud.ac.id
}

Corresponding Author: putu_sampurna@unud.ac.id

\begin{abstract}
Research on the application of the Indonesian National Standard (SNI) of Bali cattle by cluster analysis and biplot aims to provide a visual picture in the form of tables and graphs, so that it is easier and faster and more communicative in making decisions, whether the cows studied are included in class I, class II, or class III based on SNI Bali cattle. This study was conducted on 70-year-old adult female cows of 70 animals raised at the Integrated Farming System (Simantri) in Badung regency. The data obtained were analyzed by cluster analysis and biplot, as variables were shoulder height, body length and chest circumference, while as objects were 70 adult cows and 3 classes of Balinese cattle based on SNI of Bali cattle as object identifiers. The results obtained that the application of SNI for Bali cattle can be done by cluster analysis and biplot and both analyzes give the same results to the grouping of Bali cattle objects based on SNI for Bali cattle. Grouping by cluster analysis is easier to see based on the cluster membership obtained, whereas with biplot analysis provides additional information about correlations and diversity between variables.
\end{abstract}

\section{Keywords: Bali cattle, Indonesian's National Standard, Cluster, Biplot}

\section{INTRODUCTION}

Bali cattle have been established through Keputusan Minister of Agriculture Number: 325 / Kpts / OT.140 / 1/2010, as a native Indonesian cattle family and has spread throughout Indonesia. Bali cattle have an important role in providing national meat. Therefore, Bali cattle breeding standards need to be established as a reference for businesses in efforts to develop Bali cattle. The National Standardization Agency (BSN) has issued National Standards (SNI) for male and female Bali 
cattle, with quantitative requirements divided into 3 classes (classes I, II and III) as minimum requirements for Bali cattle breeding [1].

Broadly speaking there are two ways of presenting data that are often used are tables or lists and graphs or diagrams [2]. Demonstration of data with pictures (graphs) has been long and often done, and is highly recommended in an analysis. Usually the display of data in this form is more favored than the presentation in the form of tabulation of numerical data or in the form of narration, because it is more interesting, more informative because it can provide more information and is more communicative so that it is easier to understand and can be said tobe more artistic in form, composition, and colors so that it is more beautiful [3].

Multivariate analysis is a statistical analysis relating to the description or interpretation of data which involves many variables and objects together [4]. One such interpretation is the grouping of data [5]. Data grouping is organizing a large data set by dividing the data into several groups (groups). The groups formed will be able to explain the similarities and differences of the entire data studied [6]. The purpose of grouping data is to facilitate the process of analysis and interpretation of big data by dividing the data into several groups. There are several techniques in grouping a data, data can be grouped based on variables and can also be based on the object of the data. One analysis that is often used for this grouping is cluster analysis.

Cluster analysis is a multivariate analysis that aims to group objects from the data studied based on the similarity of the characteristics they have [6]. The similarity of these characteristics is usually measured using a measure of proximity between objects which can be a measure of similarity or dissimilarity.

Cluster analysis is a grouping of objects or cases into smaller groups where each group contains objects that are similar to each other [7]. Cluster analysis (cluster analysis) is one of the statistical methods that can be used to carry out a grouping process. In its grouping we use a measure that can explain the closeness between data to explain the simple group structure of complex data, which is a measure of distance. A measure of distance that is often used is the size of the Euclidean distance [8].

Dendograms describe the process of cluster formation expressed in the form of images. Horizontal lines above the dendogram show a scale that describes the 
degree of similarity, the smaller the value of the scale shows the more similar the individual [9]. The specified number of clusters is expected to produce the information needed by users, the determination of the best number of clusters by the elbow method will be the default for the characteristics process based on the case study conducted [10]. Dendrogram simulation in cluster analysis by entering the variable or object identifier of each cluster formed can be named cluster according to the characteristics of the given variable or object, thus it is easier to communicate [11].

In describing several objects and variables that have closeness, it will be impractical if presented in several graphs, so it needs analysis to combine in one graph. Biplot analysis is a double dimensional descriptive statistical technique that can be presented visually by simultaneously presenting a cluster of observations. Variable in a graph in a flat plane so that the characteristics of the object and the object of observation as well as the relative position between the object of observation with the variable can be analyzed. With Biplot, it can be shown the relationship between variables, the relative similarity between the object of observation, and the relative position between the object of observation with a variable. Basically, biplot analysis is an attempt to provide a graphic display of the data matrix $\mathrm{X}$ in a plot by overlapping vectors in low-dimensional space, usually two dimensions representing vector rows of matrix X (object images) with vectors which represent the column matrix $\mathrm{X}$ (variable image). From this graphical demonstration it is expected to obtain a description of the object [12].

Biplot is an exploratory method of analyzing variable data that can provide a graphical picture of the closeness between objects, diversity of variables, correlations between variables, and the relationship between variables and objects. In addition, biplot analysis is used to describe the relationship between variables and objects that are in high-dimensional space into lowdimensional space that is two dimensions [13]. Graphical simulations are expected to get a picture of objects, for example the closeness between objects, and descriptions of variables, both in diversity and correlation, as well as the relationship between objects and variables [12].

Both multivariate analyzes have their respective advantages, cluster analysis can be used in grouping data in large numbers of objects as well as with different scale measurement variables ranging from 
nominal to intervals [6]. Biplot analysis is able to directly display the predominant variables or variables that are the most dominant of a group of objects formed on the results of the biplot analysis display [14]. grouping of biplot analysis produces a better percentage of accuracy than clustering cluster analysis. But in general, it cannot be said that biplot analysis is better than cluster analysis in grouping data and vice versa [15]. Implementation of the Indonesian National Standard (SNI) of Bali cattle in various regions in Indonesia to determine whether Bali cattle are suitable for use by seedlings need to be classified or grouped based on objects or Bali cattle assessed based on SNI, with variables determined by SNI for Bali cattle, namely shoulder height, paniang body and chest circumference. The application of SNI for Balinese cattle to classify Balinese cattle into 3 classes of objects with identifiers which have been determined by the SNI for Balinese cattle can be done by cluster analysis and biplot. The use of cluster analysis and biplot in the application of SNI for Bali cattle can be done because both of these analyzes are multivariate analyzes that can group objects (bali cattle breeds in the value and standards determined by SNI for Bali cattle) based on variables (shoulder height, body length and circumference chest).

The purpose of this study is to provide a visual picture both in the form of tables and graphs, so that it can make decisions on female Bali cattle breeds which enter into class I, class II and class III based on SNI Bali cattle. Also accompanied by the application of cluster analysis and biplot on the application of SNI Bali cattle is expected to be more accurate and faster in making decisions to classify Bali cattle based on SNI Bali cattle and can also find out why Bali cattle which are assessed by SNI Bali cattle do not enter into the class specified by SNI bali cattle.

\section{MATERIALS AND METHODS}

The study was conducted on adult bali cattle breeding aged 24-36 months from the owner of the Integrated Farming System (Simantri) in Badung Regency, the number of samples taken was 70 animals. Samples were taken randomly from 70 cattle in several breeders, then measurements of shoulder height, body length and chest circumference were measured.

Measurements were made in the manner adopted by the Balinese cattle SNI, as follows: Shoulder Height (a): Distance from the flat surface to the highest part of 
the shoulder through the scapulla perpendicularly, measured using a measuring stick. Body Length (b): The distance from the shoulder pad (humeral tuberosity) to the tip of the sitting bone (ischii tuber), measured using a measuring stick. Chest Circumference (c): wrap the measuring tape around the chest of the back of the shoulder, measured with a measuring tape.

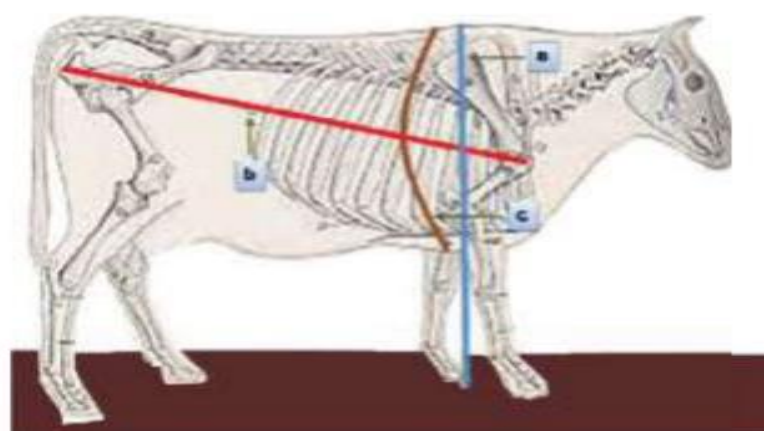

Figure 1. How to Measure Shoulder Height, Body Length and Chest Circumference

Data obtained from the results of shoulder height, body length and chest circumference from the measurement of 70 head of cattle added with class I, class II and Class III cattle objects identified based on SNI Bali cattle, namely: So the number of samples analyzed is as many as 73 pieces consisting of cattle 1 , Cow $2, \ldots \ldots .$. , cow 70, Class 1, Class II and Class III.
Table 1. Indonesian National Standard Body Size for Bali Cattle

\begin{tabular}{llccc}
\hline Age (month) & Body Size (cm) & \multicolumn{3}{c}{ Class } \\
\cline { 3 - 5 } & & I & II & III \\
\hline \multirow{3}{*}{$24-36$} & Shoulder Height & 110 & 106 & 104 \\
& Body Length & 114 & 110 & 105 \\
& Chest Circumference & 147 & 135 & 130 \\
\hline
\end{tabular}

Data from 70 female Bali cattle and 3 identifying objects or classes based on SNI were analyzed by Hierarchical Cluster. The number of groups is determined until when the class is in class grouping obtained in Cluster Membership between class I, class II and class III based on separate SNI in different classes, so that the minimum consists of 3 Cluster Membership groups if all cows can enter into 3 classes If there are cattle that cannot enter the class, more than 3 Cluster Membership groups can be formed.

The data obtained were also analyzed by biplot analysis as variables as shoulder height, body length and chest circumference, and as objects were Cattle 1, Cattle 2,.........., Cattle 70, Class I, Class II and Class III. The diversity of shoulder height, body length and chest circumference are determined based on the average vector display norm, while the mapping of objects 70 cows and 3 classes based on SNI is determined based on the location of coordinates with Factor Scores Method 
Regression Analysis Analysis procedures using SPSS 25.

\section{RESULTS DISCUSSION}

Hierarchical cluster analysis results (hierarchirnak on cal clusters) for 70 female cattle with determinantvariable SNI for class 1, class 2 and class 3 female cattle, the results of cluster membership are obtained as shown in Table 2. Table 2. It shows that from 70 Bali cattle whose shoulder height, padding length and breast circumference were measured, there were 16 cattle including grade 1 cattle, 16 cattle also included class 2 cattle and 38 cattle including grade 3 cattle.

The results of cluster analysis of 70 female Bali cattle and 3 objects identifying SNI class I, class II and class III can be drawn with a dendogram graph like Figure 2. The dendogram graph shows Bali cattle that enter class I (green box), which belongs to class II (blue box) and those entering class III (red box), each class still has sub-classes, class II seems to be the most uniform because it only consists of 2 sub-classes, while class II and class III have more than 2 sub-classes. The existence of this sub-class is due to a every class on the SNI standard for Bali cows determined by 3 criteria, namely shoulder height, body length and chest circumference, so that cattle displaying their bodies and large chest circumference cannot enter into class I criteria if their cows are short (shoulder height) small), maybe he went to class 2 or 3 , and could even form a new class. The results of cluster analysis of 70 Bali cattle over the age of 24 months are mostly in class III and none are outside the class, this shows that the Bali cattle raised in Bali cattle farms have good management.

Table 2. Membership of Clusters with SNI Identifying Variables for Adult Bali Cattle.

\begin{tabular}{llc}
\hline Group & Cattle Number & $\begin{array}{c}\text { Cattle's } \\
\text { number }\end{array}$ \\
\hline Class I & $1,2,3,4,8,9,11$, & 16 \\
& $13,15,24,36,40$, & \\
& $56,57,58$, and \\
& 59 & \\
Class II & $21,29,32,37,39$, & 16 \\
& $41,42,43,44,45$, & \\
& $46,47,62,63,68$, \\
& and 69 \\
Class III & $5,6,7,10,12,14$, \\
& $16,17,18,19,20$, & \\
& $22,23,25,26,27$, & \\
& $28,30,31,33,34$, & \\
& $35,38,48,49,50$, \\
& $51,52,53,54,55$, \\
& $60,61,64,65,66$, \\
& 67, and 70 \\
\hline
\end{tabular}

The results of the cluster analysis are divided into 3 major groups namely cattle with shoulder height, body length and chest circumference below average, close to average and above average, these results are in accordance with [6] which states that 
cluster analysis is an analysis that aims to group objects from the data studied based on the similarity of the characteristics they have. Grouping objects or cases into smaller groups where each group contains objects that are similar to each other [7]. Cluster analysis results can be used to classify female Bali cattle over the age of 24 months into 3 groups that fall into classes I, II and III and no other groups appear outside the 3 classes determined by SNI for Bali cattle. Dendogram image (Figure 2), in general, female Bali cows are divided into 3 groups that fall into class I (green), class II (blue) and III (red). The results of the grouping of 70 female Bali cattle over the age of 24 months can be divided into 3 groups: groups in class I (green), groups in class II (blue) and groups in class III (red). The results are in line with the report [15], by providing a variable or object identifier grouping can be determined and given a name in accordance with the specified identifier variable or object.

The results of the cluster analysis of the grouping of 70 adult female cattle aged over 24 months, got shoulder height, body length and chest circumference still in class I, class II and III. So, there are no adult cows over the age of 24 months, shoulder height, body length and breast circumference much smaller or much larger than SNI for Bali cows. This is consistent with the results of research by [16] who reported that the management of bali cattle housing in Simantri Badung regency was carried out semi-intensively and was also supported by the results of research [17] who reported that most or 42 out of 50 joint cattle groups in Simantri Badung regency had carried out intensive waste management. So, there is no extensive management and management of waste, so the cows raised in Simantri Badung regency all meet SNI requirements for Bali cattle.

Differences in shoulder height, body length and chest circumference in each individual female bali cow can be determined by conducting biplot analysis. Biplot graph can show the location of the coordinates of each individual female cow, so it can be seen which body size is large enough or small enough. The biplot chart can determine the diversity and correlation between shoulder height, body length and breast circumference of female Bali cattle. 


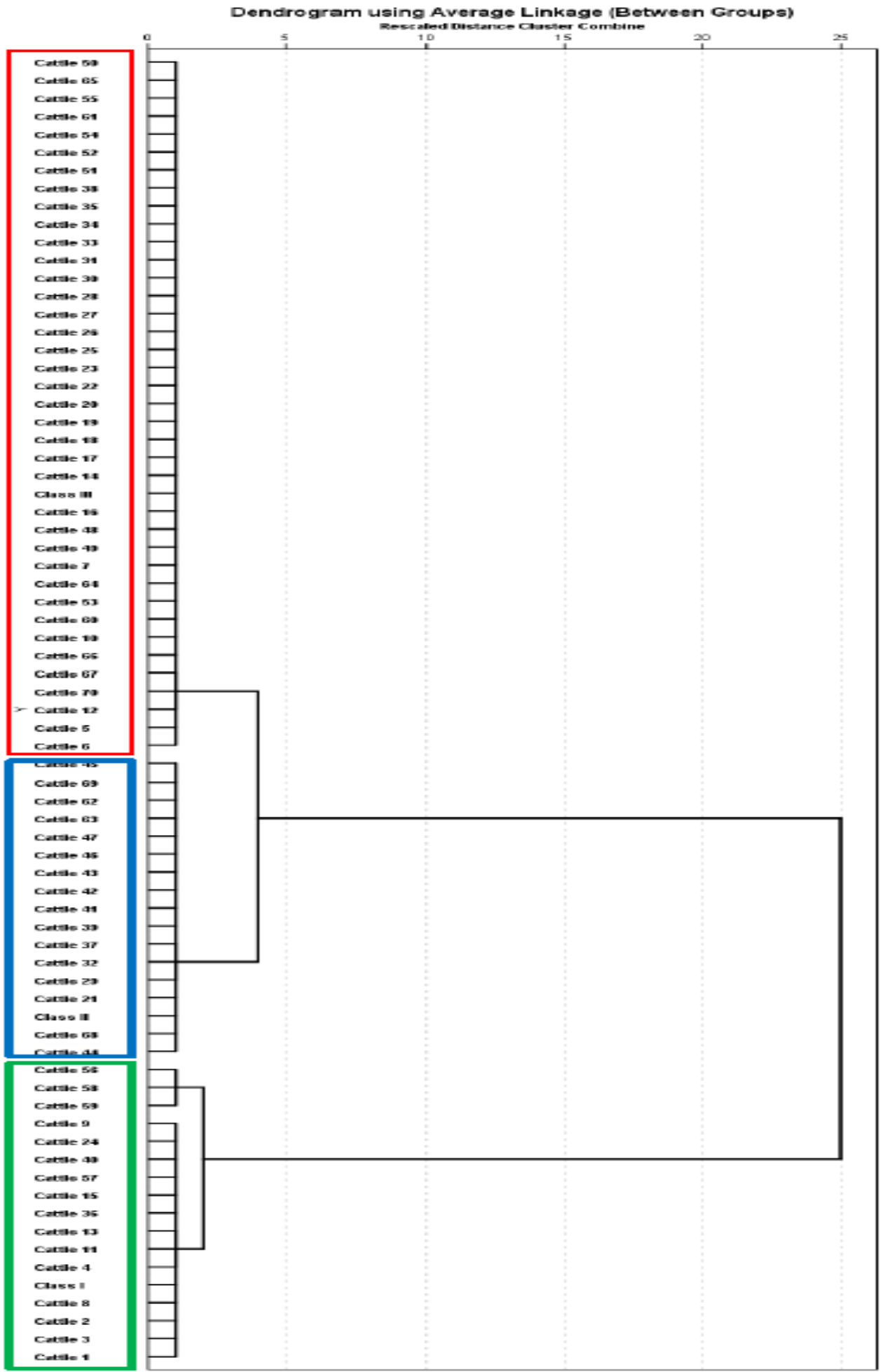

Figure 2. Dendogram of Cluster Membership with SNI Identifying Variables of Cattle in Bali Cattle. 
The results of biplot analysis showed shoulder height, body length and chest circumference to form acute angles, this indicates that the three measures were positively correlated. Thus, the length of the shoulder height vector, body length and chest circumference are close to the same, this shows that the diversity of the three variables is homogeneous diversity. [18] reported that adult Balinese cows over 24 months in length and body circumference have reached adult size or body size, cows that have reached maturity, shoulder length, body length and chest circumference have grown to reach to reach the same size if the cow comes from the same breed with the same management. Shoulder height, body length and chest circumference are positively correlated, these results indicate that the higher bali cows, the cows tend to be taller and the breast circumference is getting bigger.

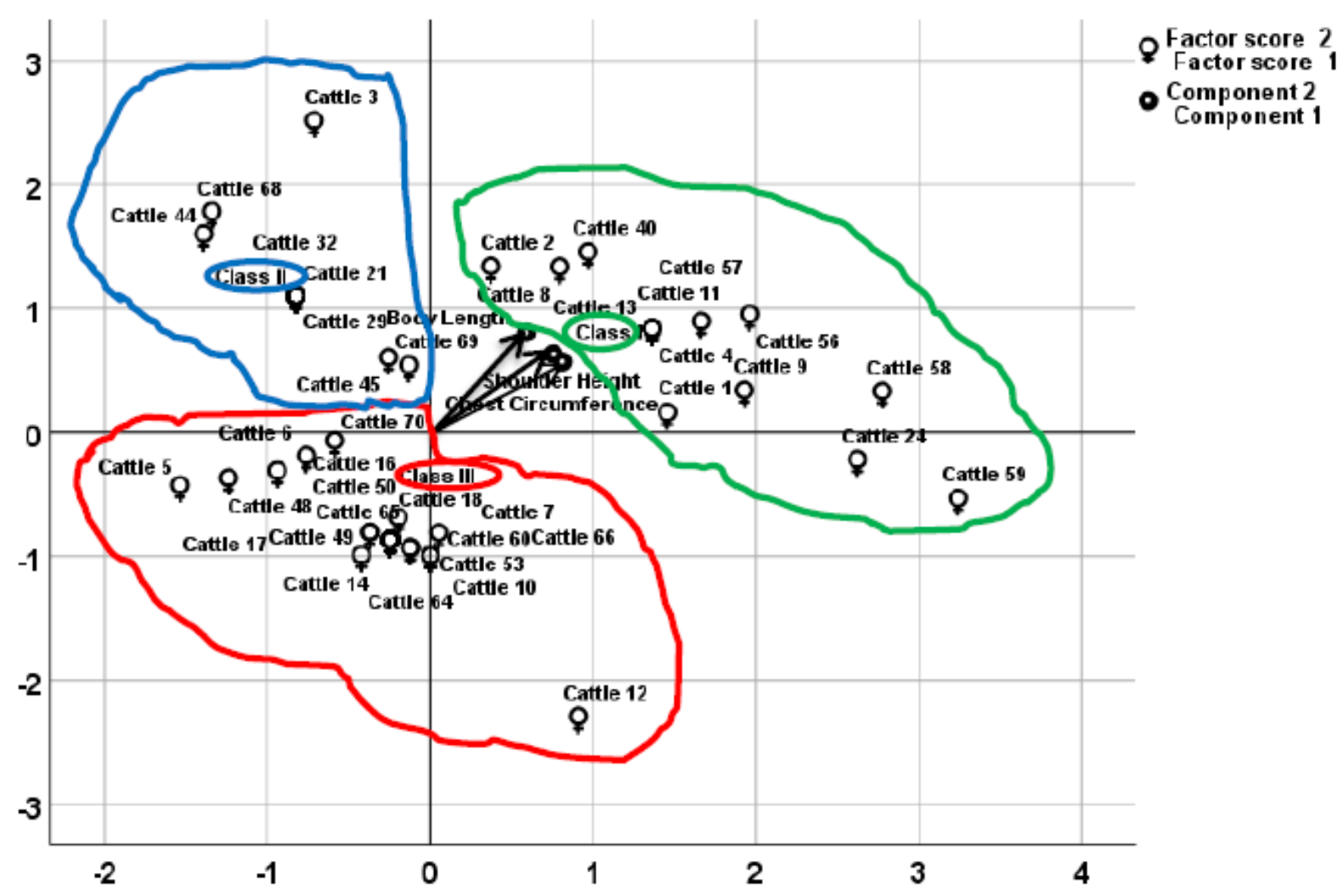

Figure 3. Biplot Graph of Adult Bali Female Cattle.

Based on the coordinates of the object in the two-dimensional space, the place is also divided into 3 groups, namely the group attached to the end of the direction of the 
arrow (green circle), including female class I cows, because class I identifiers based on SNI are in that circle. Adult cows that are in the blue circle are class II cows, because the identifying object based on SNI Bali cattle is in that circle. Likewise, adult cows that are in the red circle can be classed as class III cattle, because the object identifier based on SNI Bali cattle is in the circle. [14] stated the closeness between objects, two objects with the same characteristics will be described as two points that are close together. Objects that are located in the direction of a variable are said to have above average values. Conversely, if another object is located opposite to the direction of the variable, then the object has a value below the average. So class I cows have shoulder height, body length and chest circumference above the average, while cows with shoulder height, body length and chest circumference below the average are opposite and below the base of the arrow including class III, conversely the shoulder height, body length and chest circumference are between class I and class III including class II.

The results of clustering and biplot analysis grouping can be seen from the number of members and cows that belong to the group are the same, so grouping objects with cluster and bipalot analysis produces the same results. Cluster analysis is easier to do grouping because of the presence of membership clusters, so that it can choose the number of cluster members equal to or greater than the specified identifier object, but with biplot analysis has the advantage of getting additional information about the correlation and diversity of variables. Besides that, it can also be seen, especially in class III (directional circle), that cow that are in that class can be caused because the cow entered into class III because of its small (short) shoulder height in cow 64, cow 67 and cow 67 which is cow based on quadratic IV, which is cow, while cow 39 is in class III because the chest circumference is small (thin), while other cows that are behind the arrow (opposite direction) are dairy cows whose three variables are below average size .

\section{CONCLUSION}

Application of SNI for Bali cattle can be done by cluster analysis and biplot. Cluster and biplot analysis give the same results to the grouping of Bali cattle objects based on SNI of Bali cattle. Grouping with cluster analysis is easier to see based on the cluster membership obtained, whereas with biplot analysis provides additional 
Journal of Veterinary and Animal Sciences

DOI: https://doi.org/10.24843/JVAS.2020.v03.i02.p01

information about correlations and diversity between variables.

\section{REFERENCES}

[1] Standar Nasional Indonesia (SNI). (2017). Bibit Sapi Potong Bagia 4: Sapi Bali. Diterbitkan di Jakarta. SNI: 7651- 4:2017. ICS 65.020.30. Badan Standarisasi (BSN).

[2] Sampurna, IP. (2019). Aplikasi SPSS Grafik dalam Biostatistika. Penerbit PuriBagia

[3] Siswadi, Suharjo B. 1999. AnalisisEksplorasi Data Peubah Ganda. Bogor: Jur. Matematika FMIPA IPB.

[4] Bilodeau, Martin and Brenner. D.(1999). Theory of Multivariate Statistics. New York: Spinger. DGLS. 2003. National Report on Animal Genetic Resources Indonesia. Directorate Generale of

Livestock Services (DGLS), Directorate of Livestock Breeding. Indonesia

[5] Johnson, R. A. and D. W. Wichern. (2007). Applied Multivariat Statistical Analysis. Sixth Edition. New Jersey: Printice Hall.

[6] Everitt, B. S., Landau. S., Leese. M., dan Stahl, D. (2011). Cluster Analysis. Fifth Edition. London: John Wiley \& Sons, Ltd.

[7] Supranto, J. 2004. Analisis Multivariat Arti dan Interpretasi. Jakarta: RinekaCipta

[8] Johnson, R.A. and Wichern, D.W. (2007) Applied Multivariate Statistical Analysis. 6th Edition, Pearson Prentice Hall, Upper Saddle River.

[9] Annisa NF, Rahmawati R2, Tarnon. (2016). Analisis Klaster Kecamatan di Kabupaten Semarang Berdasarkan
pISSN 2550-1283; elSSN:2622-0571

August 2020 Vol. 3 No.2: 57-68

Potensi Desa Menggunakan Metode Ward dan Single. Jurnal Gauaaian, Volume 5, Nomor 4, Tahun 2016, Halaman 801-810. ISSN: 2339-2541. Online di: http://ejournals1.undip.ac.id/index.php/gaussian.

[10] Merliana NPE, Ernawati A, Santoso J. (2018). Analisa Penentuan Jumlah Cluster terbaik pada Metode KMeans Clustering. Posiding Seminar Nasional Multi Disiplin Ilmu\& Call for Papers Unisbank (SENDI_U) Kajian Multi Disiplin Ilmu untuk Mewujudkan Poros Maritim dalam Pembangunan Ekonomi Berbasis Kesejahteraan Rakyat ISBN: 978979-3649-81-8.

[11] Sampurna IP, Nindhia TS, Sukada IM. (2015). Dendrogram Simulations with Determinat variable Identifer to Determine the Farm Classification Systems of Bali Pigs. International Journal of Science and Research (IJSR). ISSN (Online): 2319-7064 Index Copernicus Vol. 6. Issue 10. Impact Factor (2015): 6.391

[12] Solimun dan Rinaldo A. (2008). Multivariate Analysis Aplikasi Software SPSS dan Microsoft Excell. Lembaga Pengabdian Masyarakat. Universitas Brawijaya. Malang 2008.

[13] Gabriel, K.R. (1971). The Biplot Graphic Display of Matrices with Application to Principal Componen Analysis. Biometrika 58(3): 453-467.

[14] Mattjik, A. A., dan I. M. Sumertajaya. (2011). Sidik Peubah Ganda. Bogor: Institut Pertanian Bogor Press.

[15] Ariawan IMA, Kencana IPNK, Suciptawati, NLP. (2013). Komperasi Analisis Gerombol (Cluster) dan Biplot dalam Pengelompokan. E-Jurnal Matematika Vol. 2, No.4, Nopember 2013, 17- 22 ISSN: 2303-1751. 
[16] Suputra GWK, SampurnaIP, Nindhia TS, Agustina KK. (2019). Klasterisasi Manajemen Perkandangan Sapi Bali pada Simantri di Kabupaten Badung Bali. Buletin Veteriner Udayana. Volume 11 No. 2: 128-135. pISSN: 20852495; $\quad$ eISSN: $2477-2712$ http://ojs.unud.ac.id/index.php/buleti nvet DOI: 10.24843/bulvet. 2019.v11.i02.p04

[17] Parwata, DMD, Sampurna IP, Sukada IM, Agustina, KK. (2018). Klasterisasi Manajemen Pengolahan Limbah Sapi Bali pada Simantri di
Kabupaten Badung. Buletin Veteriner Udayana Volume 11 No. 1.: 51-57. pISSN: 2085-2495; eISSN: 2477-2712. DOI: 10.24843/bulvet. 2019.v11.i01.p09

[18] Sampurna IP, Saka IK, Oka IGL, Sentana P. (2013). Biplot Simulation of Exponential Function to Determine Body Dimensions' Growth Rate of Bali Calf.Canadian Journal on Computing in Mathematics, Natural Sciences, Engineering and Medicine Vol. 4 No. 1, February 2013. 